\title{
STRATEGI PEMASARAN PRODUK BARU RECIPES MOBILE APPLICATION PT. AGRANET MULTICITRA SIBERKOM (AGRAKOM) PERIODE JULI 2011 - JUNI 2012
}

\author{
Nengsih \\ Program Studi S2 Wijawiyata Manajemen \\ Sekolah Tinggi Manajemen PPM
}

\begin{abstract}
Di tengah pertumbuhan internet yang terus berlanjut, muncul smartphone (BlackBerry, iPhone, dan Android) dan tablet iPad serta Android tablet-based. Saat ini sekitar 48 persen pengguna internet di Indonesia menggunakan ponsel untuk mengakses internet dan akan terus berlanjut dalam 12 bulan ke depan. Potensi pasar teknologi informasi dan komunikasi di Indonesia yang bisa didayagunakan dengan berkembang cepatnya pasar mobile di Indonesia mendorong PT. Agranet Multicitra Siberkom (Agrakom) atau lebih dikenal dengan Detikcom untuk mengembangkan dan memasarkan Recipes Mobile Application yang bernama Masak Apa. Pengembangan produk baru menjadi sebuah terobosan strategik untuk dapat unggul bersaing dalam industri dan untuk mencapai pertumbuhan perusahaan. Maka untuk memastikan keberhasilan pemasaran produk baru, disusunlah strategi pemasaran produk baru (marketing plan) dengan memperhatikan isu eksternal dan internal yang akan berdampak pada keberhasilan pemasaran. Penelitian ini menggunakan metode eksploratori dan riset deskriptif. Dari hasil analisis, didapatkan strategi pemasaran terpilih yaitu strategi sosialiasasi product knowledge Masak Apa kepada pangsa pasar.
\end{abstract}

Keywords:

Strategi pemasaran produk baru, recipes mobile application 


\section{PENDAHULUAN}

Di tengah pertumbuhan internet yang terus berlanjut, muncul smartphone (BlackBerry, iPhone, dan Android) dan tablet iPad serta Android tablet-based. Lembaga Survei Nielsen juga mencatat, saat ini sekitar 48 persen pengguna internet di Indonesia menggunakan ponsel untuk mengakses internet dan akan terus berlanjut dalam 12 bulan ke depan. Potensi pasar teknologi informasi dan komunikasi di Indonesia yang terlihat dengan berkembang cepatnya pasar mobile di Indonesia ini mendorong PT. Agranet Multicitra Siberkom (Agrakom) atau lebih dikenal dengan Detikcom untuk mengembangkan dan memasarkan beberapa Mobile Application salah satunya adalah aplikasi "Masak Apa”.

Detikcom adalah portal berita pertama sekaligus nomor satu di Indonesia yang diluncurkan pada 1998 dan sepenuhnya menjadi media berita pada 2004. Salah satu kanal berita Detikcom adalah DetikFood. DetikFood merupakan website tujuan nomor satu bagi penikmat kuliner di Indonesia dengan content informasi dan berita seputar dunia makanan, resep masakan, ramuan jamu, restoran, tempat kursus, dan tips memasak. DetikFood membuat segmentasi berdasarkan physchographic dan perilaku konsumen dengan menargetkan pada fun food hunter dan family food maker yang menyukai jenis makanan modern maupun tradisional, menyehatkan, dan halal.

Setelah sukses dengan kanal DetikFood dan melihat perkembangan pasar mobile maka dikembangkanlah produk baru Recipes Mobile Application bernama "Masak Apa” yang memuat resep-resep masakan yang kontennya mirip dengan konten pada kanal DetikFood.

Pengembangan produk baru ini merupakan terobosan strategik untuk dapat unggul bersaing dalam industri dan untuk mencapai pertumbuhan perusahaan. Maka untuk memastikan keberhasilan pemasaran produk baru yang ditunjukkan dengan diterimanya produk yang ditawarkan perusahaan oleh konsumen dalam jumlah download yang tinggi serta didapatkan pendapatan dari iklan, maka disusunlah strategi pemasaran produk baru (marketing plan).

Strategi pemasaran produk baru tersebut perlu direncanakan secara matang dengan memperhatikan faktor-faktor penentu keberhasilan produk baru di pasaran untuk menghindari kemungkinan gagal produk di pasaran. Sesuai dengan faktor-faktor penentu keberhasilan menurut Cooper (2001) maka perlu dilakukan riset pasar untuk memahami kebutuhan konsumen dan peluncuran produk dipersiapkan dengan matang serta dilaksanakan dengan baik. Dengan dukungan manajemen puncak guna mencapai keberhasilan pemasaran produk baru tersebut di pasar, maka penulis melakukan penelitian dengan judul "Strategi Pemasaran Produk Baru Recipes Mobile Application PT. Agranet Multicitra Siberkom (Agrakom) Periode Juli 2011 - Juni 2012”.

Strategi pemasaran produk baru yang dirancang memperhatikan isu strategis eksternal dan internal yang akan berdampak pada keberhasilan pemasaran produk inovasi yang akan diluncurkan. Dikarenakan situasi pasar untuk produk teknologi informasi sangat dinamik maka strategi pemasaran perlu diperbaharui secara periodik minimal satu tahun sekali.

Beberapa penelitian terdahulu mengenai perilaku konsumen terhadap teknologi mobile adalah sebagai berikut:

a.Penelitian Peter Tobbin dengan judul "Modeling Adoption of Mobile Money Transfer: A Consumer Behaviour Analysis". Hasil penelitian menunjukkan bahwa Perceived Ease of Use dan perceived usefulness merupakan faktor 
yang paling mempengaruhi minat konsumen dalam menggunakan mobile money di Ghana.

b.Penelitian Po-Chien Chang (2007) dengan judul "Understanding Consumers' Behaviour when Using a Mobile Phone as a Converged Device”. Hasil penelitian menyatakan bahwa meskipun Technology Acceptance Model (TAM) efektif menjelaskan perilaku konsumen dalam konteks teknologi single-function, TAM pelu diperkaya dengan menerapkan multifunction (converged) technologies.

c.Penelitian Sudarsan Jayasingh dan Uchenna Cyril Eze (2009) dengan judul "An Empirical Analysis of Consumer Behavioral Intention Toward Mobile Coupons in Malaysia". Hasil penelitian menunjukkan bahwa persepsi manfaat, persepsi kemudahan penggunaan, persepsi kredibilitas, kompatibilitas, dan faktor sosial mempengaruhi perilaku dan niat konsumen dalam menggunakan m-kupon.

d.Penelitian Norazah Mohd Suki (2011) dengan judul "Subscribers' intention using $3 G$ mobile services". Hasil penelitian menunjukkan bahwa Perceived Usefullness, Perceived Ease of Use, dan Attitude secara bersama-sama mempengaruhi minat untuk menggunakan service mobile 3G. Perceived Usefullness merupakan faktor kunci yang mempengaruhi minat untuk menggunakan service mobile $3 G$.

Hasil studi ini menegaskan bahwa, dalam konteks teknologi mobile, model adopsi tradisional seperti TAM dapat diterapkan, tetapi perlu dimodifikasi dan diperluas dalam rangka meningkatkan relevansi dengan konteks.

\section{TINJAUAN PUSTAKA}

\subsection{Telepon Seluler Pintar (Smartphone)}

Telepon seluler (ponsel) pintar (smartphone) adalah telepon genggam yang mempunyai kemampuan tingkat tinggi, kadang-kadang dengan fungsi yang menyerupai komputer. Meskipun belum ada standar pabrik yang menentukan definisi ponsel pintar, ponsel pintar dapat diartikan sebagai komputer mini yang mempunyai kapabilitas sebuah ponsel.

Sistem operasi yang dapat ditemukan di ponsel pintar adalah Symbian OS, iPhone OS, RIM BlackBerry, Windows Mobile, Linux, Palm WebOS dan Android. Android dan WebOS dibuat oleh Linux, dan iPhone OS dibuat oleh BSD dan sistem operasi NeXTSTEP berhubungan dengan Unix. Contoh dari ponsel pintar ini adalah Nokia N97, BlackBerry, LG Optimus Android, Nexian A890 Android, HTC, iPhone, dan PDA Phone.

\subsection{Mobile Applications}

Aplikasi mobile merupakan program yang berdiri sendiri dan dirancang untuk digunakan pada perangkat mobile. Setelah di-download dan diinstal pada perangkat mobile, aplikasi ini dijalankan off-line. Aplikasi mobile digunakan sebagai alternatif dari Web-Based Mobile atau mengakses informasi/referensi dari mobile browser.

Aplikasi mobile ini juga sering disebut dengan native application. Saat ini native application dikembangkan menggunakan database yang tersimpan di piranti langsung atau dengan model client server yaitu database-nya terpusat di server yang terletak terpisah dari piranti mobile. Misalnya aplikasi Facebook di iPhone dan aplikasi Kompas for BlackBerry. 
Kelebihan Native Application:

a.Loading aplikasi lebih cepat karena sudah terinstal langsung di handset.

b.Bisa cocok dan menyesuaikan dengan karakteristik piranti.

Kekurangan Native Application:

a. Cost dan effort yang lebih besar, karena harus mengembangkan aplikasi native untuk masing-masing platform.

b.Portabilitas rendah.

\subsection{Pengembangan Produk Baru (New Product Development)}

Menurut Kotler (2009),

pengembangan produk dapat diartikan sebagai pengembangan dari produk yang sudah ada atau menciptakan produk yang sama sekali baru dengan mengidentifikasi dan mengevaluasi ide produk baru dan bekerja sama dengan departemen riset penelitian dan pengembangan serta departemen-departemen lain yang ada dalam setiap tahap proses pengembangan.

Kotler dalam bukunya Marketing Management (2009) mengemukakan bahwa ada delapan proses pengembangan produk baru yaitu mencakup: pemunculan gagasan (idea generation), penyaringan gagasan (idea screening), pengembangan dan pengujian konsep (concept development and testing), pengembangan strategi pemasaran (marketing strategy development), analisis bisnis (business analysis), pengembangan produk (product development), pengujian pasar (market testing), dan komersialisasi (commercialization). Dalam setiap tahapan proses tersebut, manajemen akan mereview dan mengambil keputusan apakah lanjut atau menghentikan proses pengembangan produk baru tersebut.

\subsection{Produk Baru}

Menurut Kotler (2009), produk adalah segala sesuatu yang dapat ditawarkan ke pasar untuk memuaskan keinginan atau kebutuhan. Produk baru menurut Simamora dalam Sinta (2004) merupakan barang dan jasa yang pada dasarnya berbeda dari yang telah dipasarkan sebelumnya oleh perusahaan.

Produk baru mencakup dari produk baru di dunia (new-to-the-world products) yang menciptakan pasar yang baru, pengembangan minor pada produk, maupun revisi pada produk yang ada (Kotler, 2009). Booz, Allen \& Hamilton dalam Kotler (2000) mengidentifikasi bahwa terdapat enam kategori produk baru, yaitu:

a. produk baru dengan penciptaan pasar yang baru (new to the world products),

b.produk baru dengan pertama kali memasuki pasar yang sudah ada untuk produk semacam (new product lines),

c. produk baru hasil modifikasi produk lama (additions to existing product lines),

d.produk baru untuk menggantikan produk yang ada untuk meningkatkan kinerja dan nilai (improvements and revisions to existing products),

e.produk yang ada yang ditargetkan untuk pasar baru atau segmen baru (repositionings),

f. produk baru dengan harga lebih rendah (cost reductions).

\subsection{Siklus Hidup Produk (Product Life Cycle)}

Siklus hidup produk (PLC) menggambarkan tahap-tahap yang berbeda dalam perkembangan sejarah penjualan dari suatu produk. Dengan mengidentifikasikan tahap di mana suatu produk berada atau mungkin arah perkembangannya, perusahaan dapat memformulasikan rencana-rencana pemasaran yang lebih baik. Menurut Kotler (2009), siklus hidup produk dibagi dalam empat tahap, yakni:

a. Tahap perkenalan (introduction): Pertumbuhan penjualan lambat karena produk baru saja diperkenalkan kepada 
konsumen. Biaya sangat tinggi sehingga produk tidak menghasilkan keuntungan sama sekali.

b.Tahap pertumbuhan (growth): Pasar dengan cepat menerima produk baru sehingga penjualan melonjak dan menghasilkan keuntungan yang besar.

c. Tahap kedewasaan (majurity): Pertumbuhan penjualan mulai menurun karena produk sudah bisa diterima oleh sebagian besar pembeli potensial. Jumlah keuntungan mantap, stabil atau menurun yang disebabkan oleh meningkatnya biaya pemasaran untuk melawan persaingan yang ketat.

d.Tahap penurunan (decline): Penjualan menurun dengan tajam diikuti dengan menyusutnya keuntungan.

\subsection{Consumer Desicion Making (CDM)}

Menurut Kotler (2009), untuk sampai pada keputusan pembelian, seseorang akan melalui tahap-tahap pengambilan keputusan. Proses pembelian dimulai ketika pembeli mengenali masalah atau kebutuhan yang dapat dipicu oleh rangsangan internal atau eksternal. Konsumen yang telah terangsang kebutuhannya akan terdorong untuk mencari informasi yang lebih banyak. Selanjutnya, konsumen melakukan evaluasi alternatif. Dalam tahap evaluasi, para konsumen membentuk preferensi atas produk-produk yang ada di dalam kumpulan pilihan sebelum membeli produk. Akhirnya konsumen akan sampai pada tahapan pasca pembelian dimana konsumen akan merasakan tingkat kepuasan yang didapatkannya setelah mengkonsumsi produk yang dibelinya.

Dikarenakan perkembangan

teknologi dan persaingan bisnis, maka beberapa produk teknologi tidak perlu dibeli oleh konsumen atau gratis.

\subsection{Inovasi}

Tidd Joe, John Bessant, dan Keith Pavitt dalam bukunya yang berjudul Managing Innovation: Integrating Technological, Market and Organizational Change mengatakan inovasi berasal dari kata Latin - innovare - yang berarti "untuk membuat sesuatu yang baru”, sehingga didefinisikan sebagai suatu proses yang merubah kesempatan menjadi ide-ide baru dan menjadikannya dapat digunakan dalam praktek secara luas.

Paul Trott (2008) mengatakan inovasi adalah manajemen dari semua aktivitas yang berhubungan dengan proses penciptaan ide, pengembangan teknologi, manufaktur dan pemasaran suatu produk atau proses manufaktur atau peralatan baru (atau perbaikan). Sedangkan penemuan (invensi) merupakan proses konversi pemikiranpemikiran intelektual ke dalam artifak baru yang nyata (biasanya produk atau proses). Secara sederhana hubungan invensi dan inovasi digambarkan dalam rumus sebagai Inovasi $=$ Konsepsi teori + invensi + komersialisasi.

Sehingga, inovasi dapat dikatakan sebagai implementasi komersialisasi suatu invensi dari ide-ide dalam sebuah organisasi.

\subsection{Difusi Inovasi}

Menurut Schiffman dan Kanuk (2010), diffusi adalah bagaimana penyebaran informasi dan diasimilasikan di dalam pasar atau dikatakan adalah suatu proses di mana suatu inovasi diterima (produk baru, jasa baru, ide baru) melalui komunikasi ke anggota-anggota sistem sosial atau populasi dalam jangka waktu tertentu. Terdapat lima karakteristik produk yang memudahkan adopsi konsumen terhadap produk baru, yaitu: Relative advantage, Compatibility, Complexity, Trialibility, dan Observability (atau communicability). 


\subsection{Technology Acceptance Model} (TAM)

Model TAM (Gambar 1.) merupakan salah satu teori sistem informasi yang memodelkan bagaimana pengguna menerima dan menggunakan suatu teknologi. TAM menggunakan Theory of Reasoned Action
(TRA) sebagai basis teori untuk menspesifikasi hubungan sebab-akibat antara dua konstruk kunci: (1) Perceived Usefullness (PU) dan Perceived Ease of Use (PEOU), dan (2) Behavioral Intentions (BI) dan actual system usage behavior.

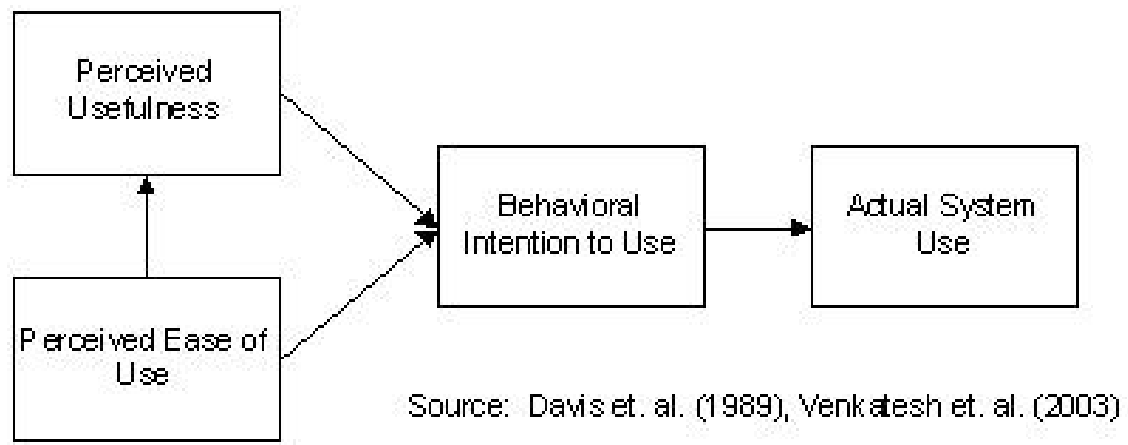

Gambar 1.

Technology Acceptance Model (TAM)

\section{METODOLOGI PENELITIAN}

\subsection{Kerangka Analisis}

Perumusan strategi pemasaran produk baru Recipes Mobile Application (Gambar 2.) menggunakan kerangka pemikiran dari Fred David yang dimulai dengan analisis eksternal dan internal perusahaan. Analisis Eksternal terdiri dari analisis lingkungan makro, analisis kondisi dalam industri dengan alat analisis FiveForces Michael Porter, serta analisis pasar. Analisis pasar didasarkan pada hasil riset proses Consumer Decision Making (CDM) dengan melihat preferensi konsumen pada Recipes Mobile Application. Sedangkan analisis internal terdiri dari analisis persaingan dengan menggunakan Competitive Profile Matrix (CPM), analisis fungsional perusahaan dalam kaitannya dengan pengembangan produk baru Recipes Mobile Application, dan posisi produk dalam tahapan Product Life Cycle.
Hasil analisis eksternal dan internal ini menghasilkan peluang, ancaman, kekuatan, dan kelemahan yang kemudian akan digunakan untuk formulasi sasaran berupa target market, posisi produk, dan profitabilitas yang hendak dicapai dalam periode satu tahun. Untuk mencapai sasaran tersebut, maka terdapat beberapa alternatif strategi pemasaran produk baru yang muncul dengan alat analisis matriks TOWS. Selanjutnya dipilih strategi pemasaran produk baru Recipes Mobile Application yang paling tepat dengan menggunakan Quantitative Strategic Planning Matrix (QSPM).

Strategi pemasaran produk baru terpilih selanjutnya didukung dengan program implementasi strategi pemasaran produk yang akan dilakukan organisasi dalam periode satu tahun (Juli 2011 - Juni 2012). Program implementasi dibahas untuk masing-masing elemen marketing mix, yaitu: produk, harga, promosi, dan distribusi. 


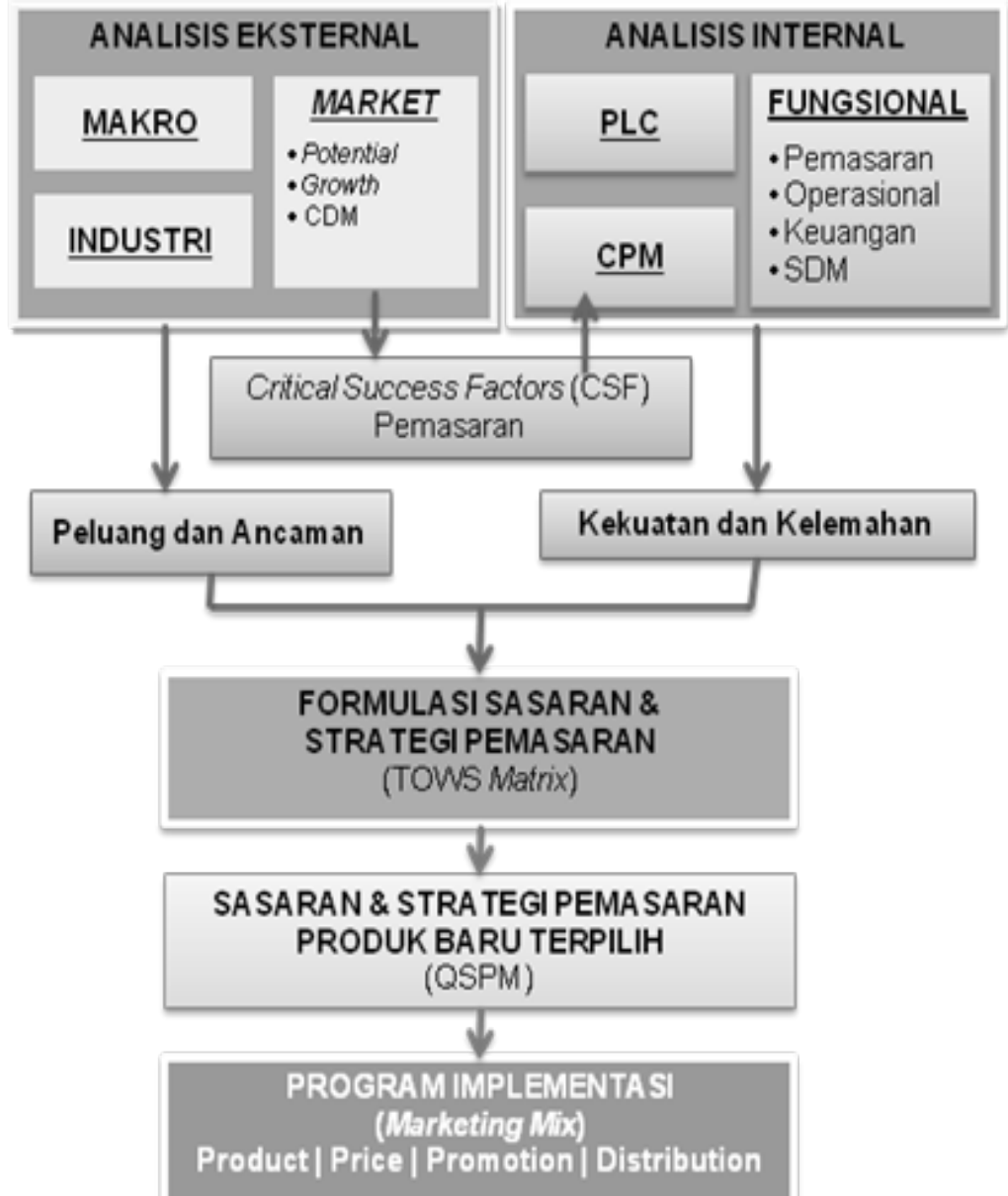

Gambar 2.

Kerangka Analisis

\subsection{Metode Pengumpulan Data}

Data penelitian yang dikumpulkan adalah data primer dan sekunder. Metode penelitian untuk pengambilan data primer bersifat kualitatif dan kuantitatif yaitu dengan menggunakan observasi, wawancara, Focus Group Discussion (FGD), kuesioner (survei online), dan Executive Judgment. Sementara metode penelitian untuk pengambilan data sekunder secara internal dan eksternal perusahaan adalah melalui data perusahaan dan studi literatur yang didalamnya mencakup profil perusahaan, buku-buku, koran, majalah, jurnal, internet, dan hasil-hasil riset lainnya yang terkait.

Focus Group Discussion (FGD) digunakan sebagai metode riset eksploratori untuk menyusun pertanyaan-pertanyaan yang relevan untuk diteliti dalam riset kuantitatif (survei online). Riset pasar yang dilakukan termasuk penelitian deskriptif mengingat tidak dilakukan pengontrolan terhadap perlakuan dengan menerapkan riset kualitatif dan kuantitatif yang bertujuan untuk mengetahui faktor-faktor yang mempengaruhi preferensi konsumen terhadap recipes mobile application. 


\subsection{Populasi dan Sampel}

Populasi dalam penelitian ini adalah para pengguna smartphone baik itu BlackBerry, Android, maupun iPhone dan tablet seperti iPad, Galaxy Tab, dan PlayBook di Indonesia. Perhitungan populasi berasal dari data Kementerian Komunikasi dan Informatika, International Data Corporation (IDC) Indonesia, dan Asosiasi Pengusaha Komputer Indonesia (Apkomindo) seperti yang ditunjukkan pada Tabel 1. dan Tabel 2. di bawah ini:

Tabel 1.

Estimasi Jumlah Smartphone di Indonesia

\begin{tabular}{||c||c||c||}
\hline $\begin{array}{c}\text { Sistem Operasi } \\
\text { Smartphone }\end{array}$ & $\begin{array}{c}\text { Q3 2010 } \\
\text { (\%) }\end{array}$ & Jumlah \\
\hline \hline Symbian & 50 & 4.054 .054 \\
\hline \hline Blackberry & 37 & 3.000 .000 \\
\hline \hline Windows Mobile & 2 & 162.162 \\
\hline \hline Android & 10 & 810.811 \\
\hline \hline iPhone & 1 & 81.081 \\
\hline \hline \multicolumn{1}{|c|}{} & & $\mathbf{8 . 1 0 8 . 1 0 8}$ \\
\hline
\end{tabular}

Sumber :

Tabel 2.

Estimasi Jumlah Personal Computer (PC) di Indonesia

\begin{tabular}{|c||c||c||}
\hline PC portabel & Persentase & Jumlah \\
\hline \hline Notebook & $65 \%$ & 2.405 .000 \\
\hline \hline Netbook & $28 \%$ & 1.036 .000 \\
\hline \hline Tablet PC & $7 \%$ & 259.000 \\
\hline \hline & $\mathbf{1 0 0 \%}$ & $\mathbf{3 . 7 0 0 . 0 0 0}$ \\
\hline
\end{tabular}

Sumber :

Dengan melakukan penjumlahan pengguna smartphone dengan pengguna tablet di Indonesia, maka dapat dihitung jumlah populasi pada penelitian ini, yaitu:

8.108.108 + 259.000 = 8.367.108.

Sampel FGD adalah pengguna smartphone dan/atau tablet di Indonesia yang bersedia menggunakan aplikasi mobile berbasis referensi resep masakan sebelum Focus Group Discussion (FGD) berlangsung. Sedangkan sampel survei online hanya dipilih berdasarkan kepemilikan smartphone atau tablet yang terdiri dari berbagai lapisan masyarakat tanpa batasan usia maupun tingkat sosial ekonomi. Karena survei dilakukan secara online maka responden merupakan pengguna internet juga.

\subsection{Metode Pengambilan Sampel}

Metode pengambilan sampel menggunakan metode non-probabilitas, dimana setiap anggota dari populasi tidak diberikan kesempatan yang sama untuk menjadi responden. Pengambilan sampel untuk riset pendahuluan dengan FGD menggunakan teknik penilaian (judgment), yaitu memilih sampel dari suatu populasi 
didasarkan pada informasi yang diberikan melalui email maupun wawancara telepon (phone interview). Sehingga perwakilannya terhadap populasi dapat dipertanggungjawabkan. Responden FGD dikelompokkan dalam dua grup dimana tiap grup kurang lebih delapan orang.

Teknik pengambilan sampel dari survei online adalah dengan cara sampel disaring (screened sample) secara online. Faktor yang digunakan untuk membatasi adalah kepemilikan smartphone atau tablet. Jumlah sampel pada survei online ditentukan berdasarkan pada rumus perhitungan sampel Slovin (Hasan, 2002) yaitu dari jumlah 8.367.108 pengguna smartphone atau tablet di Indonesia, dengan nilai kritis 5\%, maka jumlah sampel yang perlu diambil sebanyak 400 orang. Berdasarkan diskusi peneliti dengan counterpart, waktu pemasangan survei online adalah sekitar 2 minggu yaitu 28 Maret - 8 April 2011. Sehingga didapatlah sampel sebanyak 1145 responden yang melebihi batas minimum sampel berdasarkan rumus Slovin.

\subsection{Variabel dan Pengukuran}

Responden FGD adalah pengunjung DetikFood yang mendaftarkan diri untuk menjadi responden FGD dan telah lolos penyaringan yang dilakukan via email dan teleinterview. Penyaringan dilakukan dengan melihat kepemilikan smartphone dan/atau tablet serta hobi memasak dari calon responden. Kemudian, data pekerjaan responden FGD digunakan untuk pengkategorian responden ke dalam grupgrup FGD (Tabel 3.).

Tabel 3.

Pembagian Grup Focus Group Discussion

\begin{tabular}{|c||l||}
\hline \multirow{2}{*}{ Grup 1 } & $\begin{array}{l}\text { Responden yang berstatus sebagai } \\
\text { pegawai atau karyawan dan } \\
\text { mahasiswa }\end{array}$ \\
\hline \hline Grup 2 & $\begin{array}{l}\text { Ibu rumah tangga, wiraswasta, } \\
\text { wirausaha, pencari kerja, dan lain- } \\
\text { lain }\end{array}$ \\
\hline
\end{tabular}

Pengambilan data dengan panduan wawancara yang disusun secara tertulis sesuai dengan masalah, kemudian digunakan sebagai sarana untuk mendapatkan informasi. Penggunaan panduan tersebut untuk penelitian kualitiatif dengan metode FGD digunakan untuk mengkonfirmasi faktor-faktor yang mempengaruhi preferensi konsumen terhadap Recipes Mobile Application yang diperoleh melalui studi literatur dan mengkaji indikator-indikator dari factor-faktor tersebut. Dari hasil FGD ini maka disusun pertanyaan-pertanyaan dalam kuesioner untuk survei online.

Dalam penelitian dengan metode survei online dikumpulkan data profil responden atau aspek non-latent seperti halnya metode FGD, yaitu: nama, alamat, jenis kelamin, usia, status pernikahan, pendidikan, pekerjaan, pengeluaran per bulan, dan smarphone/tablet yang dimiliki. Sedangkan aspek latent mengukur faktorfaktor yang teridentifikasi dari studi literatur dan hasil analisis FGD. Variabel diukur dengan skala pengukuran rasio. Scaling technique menggunakan skala Likert yang tidak seimbang (Likert scale with unbalanced scale) untuk menghindari jawaban responden yang ragu-ragu atau netral. 


\subsection{Metode Analisis Data}

(FGD) ditranskripsi dan dianalisis menggunakan analisis domain. Analisis domain berguna untuk mencari dan memperoleh gambaran umum atau pengertian yang bersifat secara menyeluruh. Sedangkan pengolahan data survei online menggunakan bantuan perangkat lunak Microsoft Excel 2007 dan PASW versi 18.0 untuk kebutuhan analisa deskriptif untuk menghasilkan frekuensi, mean, dan modus dalam bentuk persentase maupun grafik dari faktor-faktor yang diukur. Sementara uji validitas dan reliabilitas kuesioner menggunakan perhitungan Alpha Cronbach, analisis faktor konfirmatori, dan Product Moment Pearson.

\subsection{Reliabilitas dan Validitas Data}

Hasil uji reliabilitas data untuk semua variabel (Tabel 4.) menunjukkan bahwa data reliabel dengan nilai Cronbach Alpha sebesar 0,793.

Tabel 4.

Reliability Statistics

\begin{tabular}{|r|r|}
\hline \multicolumn{2}{|c|}{ Reliability Statistics } \\
\hline \hline Cronbach's Alpha & N of Items \\
\hline \hline, 793 & 5 \\
\hline
\end{tabular}

Sedangkan hasil uji terhadap dalam penelitian ini diringkas pada Tabel 5 . variabel operasional yang akan dianalisis berikut ini.

Tabel 5.

Reliability Statistics tiap variabel

\begin{tabular}{||l||l||c||c||}
\hline \hline No. & \multicolumn{1}{|c|}{ Variabel } & Jumlah Item & Cronbach Alpha \\
\hline \hline 1 & Perceived Usefulness & 4 & 0,811 \\
\hline \hline 2 & Perceived ease of use & 4 & 0,855 \\
\hline \hline 3 & Transactional cost & 2 & 0,835 \\
\hline \hline 4 & Observability & 3 & 0,772 \\
\hline \hline 5 & Pasca Pembelian & 4 & 0,797 \\
\hline
\end{tabular}

Tabel 5. di atas menunjukkan bahwa koefesien Alpha Cronbach untuk masingmasing variabel lebih besar dari 0,60 sehingga data dinyatakan reliabel.

Uji validitas unidimensionalitas diukur dengan analisis faktor konfirmatori, yaitu jika nilai KMO Measure of Sampling Adequacy lebih besar dari 0,5 dan jika terdapat F1 (satu) faktor yang bermakna (eigen value $>1$ ), maka analisis dapat dilanjutkan. Nilai KMO Measure of Sampling Adequacy yang telah dilakukan dengan menggunakan software PASW diperoleh hasil sebesar 0,826 (Tabel 6.) dan terdapat hanya komponen 1 yang signifikan (Initial eigenvalues) $>1$, dengan demikian instrumen penelitian dikatakan valid unidimensionalitas. 
Tabel 6.

KMO and Bartlett's Test

\begin{tabular}{|l||r||}
\hline \multicolumn{2}{|l||}{ Kaiser-Meyer-Olkin Measure of } \\
Sampling Adequacy.
\end{tabular}

Hasil uji validitas kriteria yang diukur dengan cara menghitung korelasi antara skor masing-masing item dengan skor total menggunakan teknik korelasi product moment (metode interkorelasi) dengan menggunakan software PASW diperoleh hasil nilai signikansi (2-tailed) kurang dari 0,01 pada taraf nyata sebesar $1 \%$ untuk setiap indikator dari setiap variabel. Hal ini menunjukkan data indikator-indikator yang valid dan proses analisis dapat dilanjutkan.

\section{PEMBAHASAN}

\subsection{Analisis}

Dari analisis faktor-faktor eksternal makro, mikro (industri), dan pasar maka didapatkan peluang dan ancaman produk baru Recipes Mobile Application PT. Agranet Multicitra Siberkom (Agrakom).

a. Peluang :

- Pengembangan produk baru berbasis teknologi informasi mendapat dukungan penuh dari pemerintah Indonesia melalui infrastruktur hukum dan pengaturannya serta peningkatan penetrasi penggunaan data di masyarakat mendorong permintaan konsumen terhadap produk teknologi baru.

- Perkembangan industri Teknologi Informasi (TI) di Indonesia terus terdorong untuk bertumbuh sehingga perusahaan di industri Recipes Mobile Application berpeluang memperoleh keuntungan melalui pemasaran produk barunya.
- Pesatnya pengguna mobile internet di dalam negeri terutama kalangan profesional dan tersedianya anggaran khusus untuk kebutuhannya akan consumer technology (CT) dapat meningkatkan permintaan akan Recipes Mobile Application terutama pada kalangan eksekutif atau profesional.

- Semakin maraknya kemunculan tablet di seluruh dunia serta kebutuhan smartphone yang semakin meningkat memicu perkiraan peningkatan jumlah download aplikasi mobile sebanyak dua kali lipat dan perkiraan meningkatnya jumlah revenue dari aplikasi mobile sekitar tiga kali lipat dari tahun sebelumnya yaitu pada tahun 2010 memungkinkan peningkatan jumlah download terhadap recipes mobile application dan peningkatan pendapatan dari recipes mobile application.

- Pasar potensial untuk recipes mobile application cukup besar yang memungkinkan besarnya permintaan akan produk recipes mobile application saat produk ini dipasarkan.

b.Ancaman:

- Masyarakat Indonesia yang sensitif pada harga (price-sensitive), aplikasi mobile gratisan yang masih mendominasi total aplikasi di dunia sekitar 81 persen, dan konsumen baru yang akan menggunakan aplikasi berbayar hanya jika mekanisme sistem pembayaran (billing system online) sudah terjamin keamanannya menjadi ancaman bagi perusahaan di 
industri aplikasi mobile untuk memperoleh pendapatan, yaitu hanya dengan memperoleh pendapatan dari iklan di aplikasi dan aplikasinya tidak dapat dijual.

- Intensitas persaingan tinggi karena banyaknya produk pesaing asing dan kemungkinan bertambahnya pesaing lokal bersamaan dengan diterbitkannya recipes mobile application Agrakom dapat menyebabkan produk kurang laku di pasaran dan tidak mencapai sasaran pendapatan yang ditetapkan.

- Barier to entry yang rendah membuat pertumbuhan recipes mobile application cukup tinggi yang dapat meningkatkan persaingan di bisnis ini sehingga mengancam penyerapan produk oleh pasar sesuai target dan sasaran pendapatan dari produk.

- Kemudahan pembeli dalam membandingkan produk dan switching cost yang rendah membuat konsumen memilih produk dengan harga terendah dengan kualitas tertinggi dan beralih ke produk lain kapan saja.

- Banyaknya pilihan website, blog, buku resep atau komunitas masak-memasak sebagai produk pengganti dapat menyebabkan konsumen beralih ke produk substitusi yang mudah diakses dan menyediakan resep yang beragam.

Untuk mengetahui kekuatan dan kelemahan dari produk baru Recipes Mobile Application, selain dilakukan observasi langsung terhadap internal fungsional perusahaan dan product life cycle, dilakukan juga Competitive Profile Matrix yang didapat dari analisis konsumen yang dilakukan pembobotan dan dibandingkan dengan produk Sajian Sedap sebagai produk pesaing terdekat.

Penilaian dilakukan melalui metode executive judgment dengan teknik pengumpulan data berupa diskusi kelompok (group discussion) yang terdiri dari satu panel. Respondennya terdiri dari staf manajemen atau pejabat perusahaan Detikcom yang berpengalaman di bidang aplikasi mobile berbasis resep masakan. Metode executive judgment dipilih karena produk yang dijadikan objek penelitian masih dalam tahap pengembangan produk pada saat penelitian ini dilakukan. Sehingga penilaian dilakukan dengan pembandingan mockup awal produk dengan produk pesaing yang sudah jadi. Hasil executive judgment teringkas dalam tabel Competitive Profile Matrix (Tabel 7.) di bawah.

Pada Competitive Profile Matrix, hasil yang diperoleh aplikasi "Masak Apa" dari Detikcom berada pada angka 3,29, yakni pada posisi di atas aplikasi "Sajian Sedap".

Hal ini menunjukkan kelebihan yang dimiliki aplikasi "Masak Apa" menjadi atribut yang penting bagi konsumen. Sedangkan, aplikasi “Sajian Sedap” berlaku sebaliknya. Hal ini sesuai dengan hasil analisis fungsional internal perusahaan dimana perusahaan melakukan riset kebutuhan dan keinginan pasar sebelum proses pengembangan recipes mobile application dimulai, sehingga dihasilkan produk yang sesuai kebutuhan konsumen. Riset kebutuhan dan keinginan pasar ini pun dapat dilakukan karena didukung oleh dana yang tersedia untuk pengembangan aplikasi mobile cukup tinggi. Ditambah dengan tenaga kerja pengembang aplikasi mobile yang memang kompeten di bidangnya. 
Tabel 7.

Competitve Profile Matrix

\begin{tabular}{|c|c|c|c|c|c|c|c|c|}
\hline \multirow{2}{*}{\multicolumn{2}{|c|}{ Critical Success Factors }} & \multirow[b]{2}{*}{ Bobot } & \multicolumn{3}{|l|}{ Masak Apa } & \multicolumn{3}{|l|}{ Sajian Sedap } \\
\hline & & & Keterangan & Nilai & Nilai & Keterancan & Nilai & Nilai \\
\hline 1 & Perceived Usefulness & 0,18 & $\begin{array}{l}\text { Konten resep terbatas pada } \\
\text { banyaknya edisi resep yang } \\
\text { telah diunduh pengguna, fitur } \\
\text { dan interaksi terbatas }\end{array}$ & 2 & 0,36 & $\begin{array}{l}\text { Konten resep lebih bervariasi, } \\
\text { terdapat fitur cari dan daftar } \\
\text { belanja per item bahan } \\
\text { masakan, dan sharing ke } \\
\text { jejaring sosial }\end{array}$ & 4 & 0,72 \\
\hline 2 & Perceived ease of use & 0,44 & $\begin{array}{l}\text { Dapat diakses secara offline, } \\
\text { tampilan menarik, ukuran huruf } \\
\text { tepat, menu mudah dimengerti }\end{array}$ & 4 & 1,76 & $\begin{array}{l}\text { Diakses secara online, tulisan } \\
\text { kecil, label menu tidak } \\
\text { dimengerti }\end{array}$ & 2 & 0,88 \\
\hline 3 & Transactional cost & 0,20 & $\begin{array}{l}\text { Harga gratis tanpa dikenakan } \\
\text { biaya }\end{array}$ & 3 & 0,6 & $\begin{array}{l}\text { Harga gratis tanpa dikenakan } \\
\text { biaya }\end{array}$ & 3 & 0,6 \\
\hline \multirow[t]{2}{*}{4} & Observability & 0,19 & $\begin{array}{l}\text { Rencana program promosi } \\
\text { untuk aplikasi mobile online } \\
\text { dan offline serta periodik } \\
\text { dilakukan }\end{array}$ & 3 & 0,57 & $\begin{array}{l}\text { Brand aplikasi tidak popular, } \\
\text { kegiatan promosi online, } \\
\text { belum offline }\end{array}$ & 2 & 0,38 \\
\hline & & 1 & & & 3,29 & & & 2,58 \\
\hline
\end{tabular}

1. Bobot diolah dengan pair-comparison dari hasil riset preferensi konsumen terhadap variabel produk recipes mobile application

2. Nilai diolah dari hasil executive judgement di Agrakom

3. Nilai 1 sampai 4 diadaptasi dari David, F. Strategic Management menggambarkan kekuatan dan kelemahan produk terhadap faktor kriteria: $4=$ kekuatan utama, $3=$ kekuatan minor, $2=$ kelemahan minor, dan $1=$ kelemahan utama

4. Nilai tertimbang $=$ bobot $x$ nilai

Melalui uraian di atas maka dapat diketahui kekuatan dan kelemahan dari produk "Masak Apa”, yaitu:

\section{a. Kekuatan}

- Produk "Masak Apa" memiliki kemudahan dalam pemakaian karena konten yang dapat diakses tanpa koneksi internet (offline), fitur yang mudah digunakan, tampilan yang lebih menarik dan menu yang lebih mudah dimengerti.

- Dengan rencana promosi aplikasi mobile Agrakom selama ini yang akan dilakukan juga untuk aplikasi "Masak Apa” dengan beberapa penyesuaian program kegiatan dan didukung oleh tenaga marketing dan sales yang berpengalaman menyebabkan aplikasi "Masak Apa" memiliki atribut observability yang lebih baik dari pesaingnya.

b.Kelemahan

- Dibandingkan dengan pesaingnya, produk "Masak Apa” kurang memberikan manfaat kepada konsumen karena konten resep yang disediakan kurang memenuhi kebutuhan konsumen, fitur dan interaksinya kurang memenuhi keinginan atau harapan konsumen.

- Produk "Masak Apa” bukan produk lokal pertama yang memasuki industri recipes mobile application di Indonesia sehingga dibutuhkan usaha keras untuk merebut pasar yang dikuasai pesaing.

Peluang dan ancaman dari analisis lingkungan eksternal makro, industri dan pasar serta kekuatan dan kelemahan dari analisis internal selanjutnya digunakan untuk menetapkan sasaran pemasaran dan formulasi strategi pemasaran produk baru Recipes Mobile Application Agrakom untuk jangkauan waktu satu tahun mendatang.

\subsection{Sasaran}

Pasar sasaran produk "Masak Apa" adalah pengguna smartphone atau tablet di Indonesia yang suka memasak. Pasar sasaran melingkupi pengguna smartphone yang pernah menggunakan recipes mobile application maupun yang belum pernah menggunakan recipes mobile application 
dengan posisi produk Masak Apa sebagai aplikasi resep yang mudah digunakan dan menyajikan resep-resep baru setiap hari.

Selama satu tahun direncanakan mendapat jumlah download sebesar 236.273. Jika diasumsikan jumlah pasar potensial tidak bertambah hingga satu tahun ke depan, maka dalam waktu satu tahun aplikasi "Masak Apa" ditargetkan menguasai lebih dari 50\% market share industri recipes mobile application. Dan total pendapatan dengan proyeksi penjualan superoptimis dalam satu tahun adalah sebesar Rp. 540.000.000,-. Sedangkan, proyeksi pendapatan (revenue plan) produk aplikasi mobile Masak Apa dengan adanya prediksi kenaikan pendapatan dalam setahun berjumlah Rp. 249.395.478,-.

Anggaran pemasaran untuk mobile application diusahakan zero cost dengan cara sponsorship, tamu dikenakan entry fee atau dipilih media komunikasi yang gratis seperti social media, milist, dan promo internal di kanal-kanal Detikcom. Demikian pula dengan anggaran pemasaran mobile advertisement aplikasi Masak Apa yang dilakukan dengan personal selling akan menghabiskan biaya untuk profil perusahaan, transportasi, dan telepon serta entertain klien - diluar dari biaya renumerasi personil sales diupayakan seminimal mungkin. Keseluruhan persent-of-sales marketing budget adalah sebesar $50 \%$ dari target pendapatan setahun, yaitu sebesar Rp. 124.697.739,-. Alokasi marketing budget di bagi rata untuk pemasaran produk ke enduser dan pemasaran mobile advertisement ke perusahaan-perusahan Fast Moving Consumer Goods (FMCG), yaitu 50\% banding $50 \%$.

\subsection{Strategi}

Setelah didapat peluang (opportunities) dan ancaman (threats) bagi aplikasi "Masak Apa", serta kekuatan (strength) dan kelemahan (weakness) dari aplikasi "Masak Apa". Semua faktor tersebut dimasukkan sebagai faktor penyusunan TOWS Matrix yang merupakan salah satu cara dalam menggambarkan bagaimana external opportunities dan threats yang dihadapi dapat dicocokkan dengan kekuatan (strengths) dan kelemahan (weakness) produk sehingga diperoleh strategi-strategi seperti terlihat pada Tabel 8.

Adapun strategi pemasaran tahap perkenalan produk baru "Masak Apa" sesuai dengan matriks TOWS berdasarkan harga dan promosi dapat dikategorikan dalam strategi penetrasi cepat (rapid-penetration), yaitu peluncuran produk dengan harga rendah dan biaya promosi besar. Strategistrategi tersebut dikelompokkan berdasarkan kesamaan antar strategi secara relatif menjadi beberapa strategi utama berikut:

a. Sosialisasi product knowledge kepada pangsa pasar. Tujuannya adalah menyadarkan pangsa pasar mengenai keberadaaan aplikasi mobile Masak Apa.

- Kerjasama dengan pemerintah Indonesia dalam usaha penetrasi penggunaan data sehingga aplikasi "Masak Apa" lebih dikenal publik (SO3).

- Lakukan program sponsorhip kegiatan Teknologi Informasi untuk meningkatkan sosialisasi product knowledge kepada pangsa pasar (SO4).

- Sosialisasi produk secara offline dan online (SO6).

- Komunikasikan secara tepat dan dini diferensiasi produk sebagai aplikasi resep yang selalu baru dan resepnya dapat diakses secara offline (ST1).

- Mengakomodasi komunitas dari pengguna aplikasi untuk meningkatkan product knowledge (ST4).

- Edukasi pasar mengenai manfaat recipes mobile application dibandingkan dengan produk substitusi (ST5). 
Tabel 8.

Strategi-Strategi dari TOWS Matrix

\section{SO Strategies}

1. Tahap awal pemasaran dipilih target kalangan profesional/eksekutif sebagai target pemasaran (S2,O3)

2. Pengembangan produk ke versi yang baru dengan tetap mempertahankan keunggulan produk saat ini yaitu kemudahan dalam penggunaan untuk meningkatkan jumlah download dan pendapatan (S1, O4, O5)

3. Kerjasama dengan pemerintah Indonesia dalam usaha penetrasi penggunaan data sehingga aplikasi "Masak Apa" lebih dikenal publik (S2, O1)

4. Lakukan program sponsorhip kegiatan Teknologi Informasi untuk meningkatkan sosialisasi product knowledge kepada pangsa pasar (S2, O2)

5. Tekankan keunggulan ease of use sebagai diferensiasi pada program kampanye produk (S1, O5)

6. Sosialisasi produk secara offline dan online (S2, O5)

\section{ST Strategies}

1. Komunikasikan secara tepat dan dini diferensiasi produk sebagai aplikasi resep yang selalu baru dan resepnya dapat diakses secara offline (S2, T2)

2. Maksimalkan komunikasi harga kompetitif dari aplikasi (S2, T1)

3. Pertahankan dan tingkatkan competitive advantage produk dalam pengembangan produk di versi berikutnya (S1, T3)

4. Mengakomodasi komunitas dari pengguna aplikasi untuk meningkatkan product knowledge (S2, T2, T4)

5. Edukasi pasar mengenai manfaat recipes mobile application dibandingkan dengan produk substitusi (S2, T5)

6. Menciptakan customer review yang menarik $(\mathrm{S} 2, \mathrm{~T} 2, \mathrm{~T} 4, \mathrm{~T} 5)$

- Tahap awal pemasaran dipilih target kalangan profesional/eksekutif sebagai target pemasaran (SO1).

- Produk dijual dengan harga ekonomis dan bersaing untuk semua jenis platform yang dikembangkan (WT1)

- Menciptakan customer review yang menarik (ST6).

b.Menumbuhkan preferensi pangsa pasar terhadap produk Masak Apa untuk dapat merebut konsumen dari pesaing dengan memberikan persepsi mengenai produk.

\section{WO Strategies}

1. Pengembangan produk ke versi yang baru dengan meningkatkan manfaat konsumen melalui konten resep, fitur, dan interaksi produk sesuai dengan hasil riset konsumen yang telah dilakukan Agrakom untuk merebut pasar pesaing (W1,W2, O5)

2. Pengembangan produk "Masak Apa" untuk smartphone/tablet jenis lain (W2, O1, O5)

\section{WT Strategies}

1. Produk dijual dengan harga ekonomis dan bersaing untuk semua jenis platform yang dikembangkan (W2,T1,T4)

2. Pengembangan produk ke versi yang baru dengan meningkatkan manfaat konsumen melalui konten resep, fitur, dan interaksi produk sesuai dengan hasil riset konsumen yang telah dilakukan Agrakom (W1,W2, T2,T4) 
- Menciptakan customer review yang menarik (ST6).

c. Modifikasi produk (product modification):

Meningkatkan kualitas produk ke versi yang baru.

- Pengembangan produk ke versi yang baru dengan tetap mempertahankan keunggulan produk saat ini yaitu kemudahan dalam penggunaan untuk meningkatkan jumlah download dan pendapatan (SO2).

- Pengembangan produk ke versi yang baru dengan meningkatkan manfaat konsumen melalui konten resep, fitur, dan interaksi produk sesuai dengan hasil riset konsumen yang telah dilakukan Agrakom (WO1,WT2).

- Pengembangan produk "Masak Apa" untuk smartphone/tablet jenis lain (WO2).

- Pertahankan dan tingkatkan competitive advantage produk dalam pengembangan produk di versi berikutnya (ST3).

- Tahap awal pemasaran dipilih target kalangan profesional/eksekutif sebagai target pemasaran (SO1).

- Produk dijual dengan harga ekonomis dan bersaing untuk semua jenis platform yang dikembangkan (WT1).

- Menciptakan customer review yang menarik.

Alternatif strategi yang telah dikelompokkan di atas kemudian dipilih berdasarkan prioritasnya menggunakan Quantitative Strategic Planing Matrix (QSPM) matrix (Tabel 9.). Dari perhitungan QSPM seperti yang dilihat pada tabel 5 diperoleh nilai prioritas tertinggi adalah strategi sosialiasasi product knowledge dengan nilai 6,35 dan diikuti oleh strategi menumbuhkan preferensi pangsa pasar terhadap produk Masak Apa dengan nilai 5,88. Dengan demikian strategi pemasaran terpilih adalah strategi sosialiasasi product knowledge.
Strategi sosialisasi product knowledge kepada pangsa pasar merupakan prioritas bagi perusahaan untuk dilakukan dalam tahap perkenalan produknya karena jika masyarakat belum mengenal produk yang dipasarkan mana mungkin masyarakat akan membandingkannya dengan aplikasi mobile sejenis. Demikian juga, pengembangan kualitas produk ke versi yang lebih baru akan dilakukan setelah memang masyarakat telah mengenal produk dan merasa diperlukan improvisasi dari aplikasi.

\section{KESIMPULAN DAN SARAN IMPLEMENTASI}

Dari hasil pemilihan dapat disimpulkan bahwa strategi pemasaran produk Masak Apa yang terpilih adalah sosialiasasi product knowledge kepada pangsa pasar dengan tujuan menyadarkan pasar mengenai keberadaaan aplikasi mobile Masak Apa. Strategi pemasaran ini selanjutnya dibuat program implementasi selama periode Juli 2011 - Juni 2012 yang pembahasannya dibagi berdasarkan konsep bauran pemasaran (marketing mix), yaitu: produk, harga, distribusi, dan promosi.

Bauran pemasaran aplikasi Masak Apa adalah dengan mengembangkan produk untuk smartphone BlackBerry, android, iPhone, dan tablet iPad. Dengan diferensiasi sebagai resep selalu baru tiap hari dan edisi resepnya dapat diunduh sehingga dapat diakses secara offline. Aplikasi menggunakan bahasa Indonesia sebagai bahasa pengantar dan disediakan tempat pemasangan iklan sebagai sarana untuk monetisasi aplikasi. Selain itu, secara reguler menganalisis hasil review aplikasi Masak Apa melalui toko online aplikasi, email, atau internet sebagai masukan untuk perbaikan bug maupun pengembangan fitur dan interaksi dari aplikasi secara bertahap dan menjaga maintenance data resep tiap hari 
serta memperbanyak edisi resep yang bisa diunduh pengguna.

Produk dipasarkan dengan harga gratis tetapi terdapat iklan. Monetisasi produk dilakukan melalui iklan dimana harga pemasangan iklan di sediakan per paket dan per masing-masing space iklan. Biaya pemasangan iklan juga diberikan diskon sebesar 25\% dari harga paket maupun harga satuan, jika waktu penayangan advertisement minimal 12 bulan. Sedangkan, waktu penayangan advertisement minimal 6 bulan akan berlaku diskon sebesar 20\% dari harga paket maupun harga satuan.

Produk dapat diunduh kapan saja melalui toko aplikasi online BlackBerry Application World, Android Market, maupun Apple Application Store dan melalui website http://gomobile.detik.com/. Selanjutnya link ini disertakan dalam signature email yang dikirim melalui semua aplikasi mobile yang dikembangkan Agrakom. Alamat website tersebut juga dicantumkan dalam semua kanal website Agrakom (http://www.detik.com) sehingga pengguna dapat mengunduh aplikasi Masak Apa dengan mudah.

Promosi produk dilakukan secara offline dan online untuk mensosialisasikan produk baru Masak Apa kepada pangsa pasar. Tahap awal pemasaran dipilih target kalangan profesional/eksekutif sebagai target pemasaran, karena pesatnya pengguna mobile internet dan tersedianya anggaran khusus untuk consumer technology (CT) dari kalangan profesional/eksekutif di dalam negeri. Program promosi secara offline aplikasi Masak Apa adalah melakukan kerjasama dengan pemerintah Indonesia dalam usaha penetrasi penggunaan data, program sponsorhip kegiatan Teknologi Informasi, akomodasi pengguna aplikasi Masak Apa untuk membangun komunitas, dan program pemasaran rutin yang dilakukan perusahaan bagi para pengguna aplikasi mobile Masak Apa, serta melakukan periklanan di media massa.

Sedangkan promosi produk secara online dilakukan dengan memasang iklan dan artikel pada website yang terkait dengan target pasar aplikasi Masak Apa, seperti detikfood.com, detik.com, wolipop.com, dan surat dari buncit. Informasi mengenai aplikasi Masak Apa juga disebar melalui detikblog dan detikforum, social media, milist, dan mobile phone. Untuk lebih menarik perhatian, maka pada waktu tertentu perlu dilakukan undian berhadiah dalam bentuk quiz maupun riset review konsumen mengenai aplikasi.

Melalui berbagai sarana promosi perlu diciptakan customer review terhadap aplikasi Masak Apa yang "menarik" di antara penggemar aplikasi, karena review itu akan menyebar di antara keluarga mereka, teman, kolega, dan pengguna lain sebagai bentuk word-of-mouth. Selain itu, dilaksanakan pengawasan dan pengendalian program pemasaran secara berkala pada saat eksekusi supaya sesuai dengan program yang telah direncanakan.

Pemasaran mobile advertisement Masak Apa menekankan pada pendekatan push atau below the line dengan personal selling, yaitu penjualan mobile advertisement dengan melakukan kontak langsung melalui salesman yang dilakukan dengan strategi jemput bola. Dalam hal ini dibutuhkan salesman yang berkompetensi untuk memprospek, mempresentasikan mobile advertisement dengan menarik, melakukan negosiasi yang cerdik, berespon cepat, dan menjaga hubungan baik dengan pelanggan sampai dengan memberikan layanan purna jual. 
VI. SARAN

\section{PENELITIAN}

\section{BERIKUTNYA}

Keterbatasan dalam penelitian ini adalah waktu yang terbatas untuk penyelesaian penelitian ini dan penelitian sebelumnya mengenai aplikasi mobile yang terbatas pada saat penelitian ini dilakukan.

Beberapa saran yang diajukan untuk penelitian berikutnya adalah:

a.Penelitian yang sama untuk periode satu tahun berikutnya setelah produk diluncurkan ke pasar sehingga dapat dilakukan pembandingan produk jadi dengan produk pesaing dari sudut pandang pengguna produk.

b.Perluasan faktor-faktor yang diteliti dalam mempengaruhi preferensi konsumen terhadap Recipes Mobile Application. 
Tabel 9.

Quantitative Strategic Planing Matrix (QSPM)

\begin{tabular}{|c|c|c|c|c|c|c|c|c|}
\hline \multirow{2}{*}{\multicolumn{2}{|c|}{ Critical Success Factors }} & \multirow[t]{2}{*}{ Bobot } & \multicolumn{2}{|c|}{$\begin{array}{c}\text { Sosialisasi product } \\
\text { knowledge }\end{array}$} & \multicolumn{2}{|c|}{\begin{tabular}{|c|} 
Menumbuhkan \\
preferensi pangsa pasar \\
terhadap produk
\end{tabular}} & \multicolumn{2}{|c|}{$\begin{array}{l}\text { Meningkatkan kualitas } \\
\text { produk ke versi yang } \\
\text { baru }\end{array}$} \\
\hline & & & Nilai & \begin{tabular}{|c|} 
Nilai \\
Tertimbang
\end{tabular} & Nilai & \begin{tabular}{|c|} 
Nilai \\
Tertimbang
\end{tabular} & Nilai & \begin{tabular}{|c|} 
Nilai \\
Tertimbang
\end{tabular} \\
\hline \multicolumn{9}{|c|}{ Peluang (Opportunities) } \\
\hline 1 & $\begin{array}{l}\text { Pengembangan produk baru berbasis teknologi informasi mendapat } \\
\text { dukungan penuh dari pemerintah Indonesia melalui infrastruktur hukum dan } \\
\text { pengaturannya serta peningkatan penetrasi penggunaan data di masyarakat } \\
\text { mendorong permintaan konsumen terhadap produk teknologi baru. }\end{array}$ & 0,03 & 4 & 0,13 & 3 & 0,10 & 2 & 0,07 \\
\hline 2 & $\begin{array}{l}\text { Perkembangan industri TI di Indonesia terus terdorong untuk bertumbuh } \\
\text { sehingga perusahaan di industri Recipes Mobile Application berpeluang } \\
\text { memperoleh keuntungan melalui pemasaran produk barunya. }\end{array}$ & 0,06 & 4 & 0,22 & 2 & 0,11 & 3 & 0,17 \\
\hline 3 & $\begin{array}{l}\text { Pesatnya pengguna mobile internet di dalam negeri terutama kalangan } \\
\text { profesional dan tersedianya anggaran khusus untuk kebutuhannya akan } \\
\text { consumer technology (CT) dapat meningkatkan permintaan akan Recipes } \\
\text { Mobile Application terutama pada kalangan eksekutif atau profesional. }\end{array}$ & 0,10 & 3 & 0,30 & 4 & 0,40 & 2 & 0,20 \\
\hline 4 & $\begin{array}{l}\text { Semakin maraknya kemunculan tablet di seluruh dunia serta kebutuhan } \\
\text { smartphone yang semakin meningkat memicu perkiraan peningkatan jumlah } \\
\text { download aplikasi mobile sebanyak dua kali lipat dan perkiraan } \\
\text { meningkatnya jumlah revenue dari aplikasi mobile sekitar tiga kali lipat dari } \\
\text { tahun sebelumnya yaitu pada tahun } 2010 \text { memungkinkan peningkatan jumlah } \\
\text { download terhadap recipes mobile application dan peningkatan pendapatan } \\
\text { dari recipes mobile application. }\end{array}$ & 0,11 & 4 & 0,44 & 3 & 0,33 & 2 & 0,22 \\
\hline 5 & $\begin{array}{l}\text { Pasar potensial untuk recipes mobile application cukup besar yang } \\
\text { memungkinkan besarnya permintaan akan produk recipes mobile application } \\
\text { saat produk ini dipasarkan. }\end{array}$ & 0,17 & 4 & 0,67 & 3 & 0,50 & 2 & 0,33 \\
\hline \multicolumn{9}{|c|}{ Ancaman (Threats ) } \\
\hline 1 & \begin{tabular}{|l|} 
Masyarakat Indonesia yang sensitif pada harga (price-sensitive), aplikasi \\
mobile gratisan yang masih mendominasi total aplikasi di dunia sekitar 81 \\
persen, dan konsumen baru yang akan menggunakan aplikasi berbayar hanya \\
jika mekanisme sistem pembayaran (billing system online) sudah terjamin \\
keamanannya menjadi ancaman bagi perusahaan di industri aplikasi mobile \\
untuk memperoleh pendapatan, yaitu hanya dengan memperoleh pendapatan \\
dari iklan di aplikasi dan aplikasinya tidak dapat dijual.
\end{tabular} & 0,09 & 4 & 0,36 & 3 & 0,27 & 2 & 0,18 \\
\hline 2 & \begin{tabular}{|l|} 
Intensitas persaingan tinggi karena banyaknya produk pesaing asing dan \\
kemungkinan bertambahnya pesaing lokal bersamaan dengan diterbitkannya \\
recipes mobile application Agrakom dapat menyebabkan produk kurang laku \\
di pasaran dan tidak mencapai sasaran pendapatan yang ditetapkan.
\end{tabular} & 0,11 & 2 & 0,22 & 4 & 0,44 & 3 & 0,33 \\
\hline 3 & $\begin{array}{l}\text { Barier to entry yang rendah membuat pertumbuhan recipes mobile } \\
\text { application cukup tinggi yang dapat meningkatkan persaingan di bisnis ini } \\
\text { sehingga mengancam penyerapan produk oleh pasar sesuai target dan } \\
\text { sasaran pendapatan dari produk. }\end{array}$ & 0,11 & 2 & 0,22 & 4 & 0,44 & 3 & 0,33 \\
\hline 4 & $\begin{array}{l}\text { Kemudahan pembeli dalam membandingkan produk dan switching cost yang } \\
\text { rendah membuat konsumen memilih produk dengan harga terendah dengan } \\
\text { kualitas tertinggi dan beralih ke produk lain kapan saja. }\end{array}$ & 0,09 & 2 & 0,18 & 3 & 0,27 & 4 & 0,36 \\
\hline 5 & $\begin{array}{l}\text { Banyaknya pilihan website, blog, buku resep atau komunitas masak-memasak } \\
\text { sebagai produk pengganti dapat menyebabkan konsumen beralih ke produk } \\
\text { substitusi yang mudah diakses dan menyediakan resep yang beragam. }\end{array}$ & 0,13 & 4 & 0,53 & 3 & 0,40 & 2 & 0,27 \\
\hline Tota & & 1 & & & & & & \\
\hline \multicolumn{9}{|c|}{ Kekuatan (Strengths) } \\
\hline 1 & $\begin{array}{l}\text { Produk "Masak Apa" memiliki kemudahan dalam pemakaian karena konten } \\
\text { yang dapat diakses tanpa koneksi internet (offline), fitur yang mudah } \\
\text { digunakan, tampilan yang lebih menarik dan menu yang lebih mudah } \\
\text { dimengerti. }\end{array}$ & 0,23 & 4 & 0,92 & 3 & 0,69 & 2 & 0,46 \\
\hline 2 & $\begin{array}{l}\text { Dengan rencana promosi aplikasi mobile Agrakom selama ini yang akan } \\
\text { dilakukan juga untuk aplikasi "Masak Apa" dengan beberapa penyesuaian } \\
\text { program kegiatan dan didukung oleh tenaga marketing dan sales yang } \\
\text { berpengalaman menyebabkan aplikasi "Masak Apa" memiliki atribut } \\
\text { observability yang lebih baik dari pesaingnya. }\end{array}$ & 0,23 & 3 & 0,69 & 4 & 0,92 & 2 & 0,46 \\
\hline \multicolumn{9}{|c|}{ Kelemahan (Weaknesses) } \\
\hline 1 & $\begin{array}{l}\text { Dibandingkan dengan pesaingnya, produk "Masak Apa" kurang memberikan } \\
\text { manfaat kepada konsumen karena konten resep yang disediakan kurang } \\
\text { memenuhi kebutuhan konsumen, fitur dan interaksinya kurang memenuhi } \\
\text { keinginan atau harapan konsumen. }\end{array}$ & 0,38 & 3 & 1,15 & 1 & 0,38 & 4 & 1,54 \\
\hline 2 & $\begin{array}{l}\text { Produk "Masak Apa" bukan produk lokal pertama yang memasuki industri } \\
\text { recipes mobile application di Indonesia sehingga dibutuhkan usaha keras } \\
\text { untuk merebut pasar yang dikuasai pesaing. }\end{array}$ & 0,15 & 2 & 0,31 & 4 & 0,62 & 3 & 0,46 \\
\hline Tota & & 1 & & 6,35 & & 5,88 & & 5,38 \\
\hline
\end{tabular}

Catatan:

1. Bobot diberikan sesuai dengan seberapa penting masing-masing faktor terhadap keberhasilan pemasaran produk dengan metode pair-comparison

2. Bobot dan nilai diolah dari hasil wawancara dengan pihak manajemen Agrakom

3. Nilai 1 sampai 4 diadaptasi dari David, F. Strategic Management menggambarkan daya tarik relatif (Attractiveness Scores) dari masing-masing strategi dimana 1 = tidak menarik, 2 = agak menarik, 3 = cukup menarik, 4 = sangat menarik

4. Nilai tertimbang $=$ bobot $x$ nilai 


\section{DAFTAR PUSTAKA}

Chang, Po-Chien. 2007. Understanding Consumers' Behaviour when Using a Mobile Phone as a Converged Device. http://www.acis2007.usq.edu.au/assets/papers/87.pdf (diunduh 10 Februari 2011).

Cooper, Robert G. 2001. Winning at New Products: Accelerating The Process From Idea to Launch. 3th Edition. Cambridge, Massachusetts: Perseus Publishing.

David, Fred R. 2009. Strategic Management Concepts. 13th Edition. New Jersey: Prentice-Hall, Inc.

Hasan, M.I. 2002. Pokok-Pokok Materi Metodologi Penelitian dan Aplikasinya. Jakarta: Ghalia Indonesia. Jayasingh, Sudarsan \& Eze, Uchenna C. 2009. An Empirical Analysis of Consumer Behavioral Intention Toward Mobile Coupons in Malaysia. http://www.knowledgetaiwan.org/ojs/index.php/ijbi/article/viewFile/ 178/62 (diunduh 14 Februari 2011).

Kotler, Philip. 2000. Marketing Management. The Millenium Edition. New Jersey: Prentice-Hall, Inc.

Kotler, Philip dan Keller, K. L. 2009. Marketing Management. 13th Edition. New Jersey: Pearson Education.

Schiffman Leon G., Kanuk Leslie Lazar. 2010. Consumer Behavior. 11th Edition. New Jersey: Pearson Educational International.

Suki, Norazah Mohd. 2011. Subscribers' intention towards using $3 G$ mobile services. http://ifrnd.org/JEBS/2\%20(2)\%20Feb\%202011/Subscribers\%E2\%80\%99\%20intention_towards\% 20using\%203G\%20mobile\%20services.pdf (diunduh 17 Maret 2011).

Tidd Joe, John Bessant, and Keith Pavitt. 2005. Managing Innovation: Integrating Technological, Market and Organizational Change. 3rd Edition. USA: John Wiley \& Sons, Ltd.

Tobbin, Peter. Modeling Adoption of Mobile Money Transfer: A Consumer Behaviour Analysis. http://vbn.aau.dk/files/43733959/ TOBBIN_paper_m4d_1.pdf (diunduh 09 Februari 2011).

Trott, Paul. 2008. Innovation Management and New Product Development. 4th Edition. New Jersey: Pearson Educatio. 